\title{
PENERAPAN PENDEKATAN SAINTIFIK UNTUK MENINGKATKAN KEMAMPUAN KOMUNIKASI MATEMATIS SISWA SEKOLAH MENENGAH PERTAMA
}

\section{IMPLEMENTATION OF THE SCIENTIFIC APPROACH TO ENHANCING MATHEMATICAL COMMUNICATION ABILITY OF JUNIOR HIGH SCHOOL STUDENT}

\author{
Laila Hayati $^{1^{*}}$, Mulyani \\ ${ }^{1}$ Program Studi Pendidikan Matematika, Jurusan Pendidikan MIPA, FKIP, Universitas Mataram, Indonesia \\ ${ }^{2}$ Guru Matematika Sekolah Menengah Pertama Negeri 5 Mataram, Nusa Tenggara Barat, Indonesia \\ *Email: lailahayati.fkip@unram.ac.id
}

Diterima: 18 Januari 2019. Disetujui: 11 Februari 2019. Dipublikasikan: 31 Maret 2019

\begin{abstract}
Abstrak: Penelitian ini bertujuan untuk meningkatkan kemampuan komunikasi matematis siswa kelas IX-H SMPN 5 Mataram materi pokok persamaan dan fungsi kuadrat dengan pendekatan saintifik tahun ajaran 2018/2019. Penelitian tindakan kelas ini terdiri dari 2 siklus, menggunakan model Kemmis \& Taggart yang terdiri dari: perencanaan, pelaksanaan, observasi, dan refleksi. Siklus 1 terdiri dari 3 kali pertemuan, dan siklus 2 terdiri dari 4 kali pertemuan. Hasil penelitian menunjukkan bahwa adanya peningkatan aktivitas belajar siswa, siklus 1 berkategori aktif, dan siklus 2 berkategori sangat aktif. Nilai rata-rata kemampuan komunikasi matematis pada siklus 1 adalah 68,05 dengan ketuntasan belajar klasikal sebesar 26,32\% dan pada siklus 2 adalah 71,38 dengan ketuntasan belajar klasikal sebesar 52,63\%. Ketuntasan belajar klasikal belum memenuhi indikator kinerja, karena kurang dari $85 \%$ siswa yang memperoleh nilai $\geq 70$ disetiap akhir siklus.
\end{abstract}

Kata kunci : Kemampuan komunikasi matematis, pendekatan saintifik, persamaan dan fungsi kuadrat.

\begin{abstract}
This research aims to enhancing the mathematical communication ability of class IX-H SMPN 5 Mataram students' in equations and quadratic functions using the scientific approach of the 2018/2019 school year. This classroom action research consists of 2 cycles, using the Kemmis \& Taggart model: planning, acting, observing, and reflecting. Cycle 1 consists of 3 meetings, and cycle 2 consists of 4 meetings. The results showed that there was an enhanced in student learning activities, the first cycle was active, and the second cycle was very active. The average value of mathematical communication ability in cycle 1 is 68.05 with classical completeness $26.32 \%$ and in cycle 2 it is 71.38 with classical completeness $52.63 \%$. Classical completeness has not met performance indicators, because less than $85 \%$ of students get a value of $\geq 70$ at the end of each cycle.
\end{abstract}

Keywords: Mathematical communication ability, scientific approach, equation and quadratic function

\section{PENDAHULUAN}

Persamaan dan fungsi kuadrat merupakan salah satu materi fundamental dalam pembelajaran matematika, khususnya aljabar [1,2], dan menantang secara konseptual dalam kurikulum $[3,4]$. Untuk itu, mengembangkan kemampuan memahami dan menyelesaikan masalah terkait materi tersebut sangat penting. Pentingnya karena digunakan untuk mempelajari materi polinom dengan pangkat yang lebih tinggi, fungsi rasional, dan hubungan antara berbagai topik [5]. Namun, beberapa hasil penelitian menunjukkan siswa mengalami kesulitan dan membuat berbagai kesalahan dalam menyelesaikan masalah persamaan kuadrat [5-9]. Beberapa kesalahan yang dibuat siswa secara umum: kesalahan aplikasi/ metode, kesalahan prosedural, dan kesalahan konseptual. Sebagian besar siswa berada pada level instrumental/ prosedural $[3,10,11]$. Kesulitan dan kesalahan tersebut sebagai akibat dari kelemahan siswa dalam menguasai topik aljabar, pecahan, bilangan bulat, aturan metode persamaan kuadrat, perhitungan dan penyederhanaan aljabar [5]. Hal tersebut berkaitan dengan rendahnya kemampuan komunikasi matematis siswa. Hasil penelitian Tiffany et. al. [12], capaian yang paling rendah terutama pada aspek menjelaskan ide matematis secara tertulis, performans siswa lebih baik pada konteks masalah menggunakan simbol daripada kata-kata [6].

NCTM [13] menyatakan bahwa komunikasi merupakan salah satu standar proses dalam matematika. Dengan memiliki kemampuan komunikasi matematis, dapat meningkatkan capaian dan pemahaman konsep [14]. Selama ini, pembelajaran di sekolah umumnya difokuskan pada prosedur dan rumus untuk mendapatkan jawaban yang benar daripada mengajarkan konsep matematika dasar dan logika di balik proses yang dilakukan [9]. Pembelajaran seharusnya membantu siswa untuk mengkomunikasikan ide matematis dengan representasi, mendengar, membaca, diskusi, dan menulis [15]. 
Salah satu pendekatan yang dapat digunakan meningkatkan kemampuan komunikasi matematis adalah pendekatan saintifik. Pembelajaran dengan pendekatan ilmiah hasilnya lebih efektif dibandingkan pembelajaran konvensional karena memuat serangkaian aktivitas pengumpulan data melalui observasi, mengolah informasi atau data, menganalisis, memformulasi, dan menguji hipotesis [16].

Langkah-langkah yang dilakukan dalam pembelajaran pendekatan saintifik [17]: (1) Mengamati: mengamati objek matematika, fenomena alam atau lingkungan; (2) Menanya: berpikir divergen; (3) Mengumpulkan informasi: mengumpulkan kebenaran matematis, mencoba, mengaitkan teorema; (4) Mengasosiasi: memperluas konsep, membuktikan, (5) Mengkomunikasikan: menyimpulkan, dan mengaitkan dengan konsep lain.

Untuk mengukur kemampuan komunikasi matematis siswa dalam memahami materi persamaan dan fungsi kuadrat, peneliti menggunakan indikator $[13,18]$, namun hanya 3 indikator yang digunakan dalam penelitian ini. Adapun indikator tersebut disajikan pada Tabel 1.

Tabel 1: Indikator Kemampuan Komunikasi Matematis

\begin{tabular}{|c|c|}
\hline No. & $\begin{array}{c}\text { Indikator Kemampuan Komunikasi } \\
\text { Matematis }\end{array}$ \\
\hline 1. & $\begin{array}{l}\text { Menggunakan pendekatan bahasa (notasi, } \\
\text { istilah, lambang), representasi matematis } \\
\text { (rumus, diagram, gambar, tabel, grafik) } \\
\text { untuk menyatakan/ menjelaskan informasi } \\
\text { matematis. }\end{array}$ \\
\hline 2. & $\begin{array}{l}\text { Menjelaskan ide, situasi, dengan gambar, } \\
\text { ekspresi, atau bahasa sendiri dengan } \\
\text { tulisan. }\end{array}$ \\
\hline 3. & $\begin{array}{l}\text { Menyusun argumen, dan } \\
\text { kesimpulan. }\end{array}$ \\
\hline
\end{tabular}

\section{METODE PENELITIAN}

Penelitian ini dilakukan di kelas IX-H SMP Negeri 5 Mataram yang berlokasi di Jl. Lalu Mesir No. 2A, Babakan, Sandubaya, Lombok, Nusa Tenggara Barat (NTB) semester ganjil tahun ajaran 2018/2019. Penelitian tindakan kelas ini mengadaptasi model Kemmis \& Taggart [19] yang terdiri dari beberapa tahap, yaitu: perencanaan, pelaksanaan, observasi, dan refleksi. Penelitian tindakan kelas adalah metode untuk menemukan aktivitas terbaik dalam kelas sehingga guru dapat memperbaiki pembelajaran siswa. Penelitian ini terdiri dari 2 siklus dengan pertimbangan bahwa materi Persamaan dan Fungsi Kuadrat terdiri dari 2 kompetensi dasar yaitu persamaan kuadrat dan fungsi kuadrat. Siklus 1 membahas materi persamaan kuadrat dalam 3 kali pertemuan dan siklus 2 membahas materi fungsi kuadrat dalam 4 kali pertemuan. Langkah-langkah yang dilakukan dalam penelitian tindakan kelas ini adalah:

1. Tahap perencanaan: kegiatan yang dilakukan pada tahap ini adalah menyiapkan RPP materi pokok persamaan dan fungsi kuadrat, menyiapkan Lembar latihan siswa/ lembar kerja siswa yang diberikan pada setiap pertemuan, menyiapkan lembar observasi guru dan siswa, menyusun kisi-kisi soal evaluasi, dan menyiapkan soal evaluasi lengkap dengan pedoman penskorannya.

2. Tahap pelaksanaan: kegiatan yang dilakukan pada tahap ini adalah melaksanakan kegiatan belajar mengajar di kelas dengan menggunakan pendekatan saintifik berpedoman pada RPP yang telah dibuat.

3. Tahap observasi: pada tahap ini dilakukan observasi terhadap aktivitas guru dan siswa, juga keterlaksanaan pembelajaran berdasarkan pendekatan saintifik. Kegiatan observasi dilakukan secara kontinu pada setiap pertemuan. Semua aktivitas tersebut dicatat dalam lembar observasi yang telah disiapkan.

4. Tahap refleksi: hasil yang diperoleh pada tahap observasi dan evaluasi di analisis. Dari hasil observasi dan evaluasi pada siklus 1, guru mengidentifikasi kesalahan dan kekurangan, penyebab kekurangan dan melakukan perbaikan di siklus 2 .

Subyek penelitian adalah siswa kelas IX-H SMP Negeri 5 Mataram yang berjumlah 38 siswa. Teknik pengumpulan data adalah dengan memberikan tes uraian dan melalui observasi dan dokumentasi. Tes digunakan untuk mengetahui peningkatan nilai rata-rata dan persentase ketuntasan belajar siswa. Observasi digunakan untuk mengetahui memperoleh data mengenai aktivitas guru dan siswa serta keterlaksanaan pembelajaran. Observasi dilakukan oleh guru SMP Negeri 5 Mataram.

Adapun indikator kinerja yang ditetapkan dalam penelitian ini adalah:

1. Aktivitas belajar siswa dikatakan tercapai apabila terjadi peningkatan skor rata-rata aktivitas belajar siswa dan minimal berkategori aktif di setiap akhir siklus.

2. Hasil belajar siswa dikatakan tercapai apabila terjadi peningkatan nilai rata-rata siswa dari siklus 1 ke siklus 2, dengan ketuntasan klasikal minimal 85\% di setiap akhir siklus (nilai $\geq 70$ ).

\section{HASIL DAN PEMBAHASAN}

Pembelajaran dengan pendekatan saintifik pada siklus 1 dilaksanakan 3 kali pertemuan. Materi yang dibahas adalah persamaan kuadrat. 
Total waktu untuk siklus 1 adalah 7x40 menit, dan evaluasi siklus 1 selama 1x40 menit. Tahap-tahap yang dilakukan pada siklus 1 adalah perencanaan, pelaksanaan, observasi, dan refleksi. Hasil observasi skor rata-rata pada siklus 1 adalah 14,67 dengan kategori aktif.

Evaluasi siklus 1 diikuti oleh 38 siswa. Evaluasi dilakukan untuk mendapatkan data kemampuan komunikasi matematis siswa setelah mengikuti pembelajaran dengan pendekatan saintifik. Evaluasi dilakukan dengan pemberian tes tulis berbentuk uraian yang berjumlah 4 soal. Hasil tes kemampuan komunikasi matematis siswa pada siklus 1 hanya $26,32 \%$ siswa yang tuntas, dan nilai rata-rata 68,50. Hal ini menunjukkan bahwa kemampuan komunikasi matematis siswa belum mencapai indikator kinerja yang ditetapkan. Untuk itu, dilanjutkan ke siklus 2. Tidak tercapainya hasil belajar sesuai dengan indikator kinerja yang telah ditetapkan, dipengaruhi oleh kekurangankekurangan yang terjadi pada siklus 1 , diantaranya banyak siswa yang tidak memperhatikan pelajaran dengan sungguh-sungguh, siswa belum berani mengemukakan pendapatnya apabila ditanya oleh guru, siswa belum terbiasa mengikuti langkahlangkah pendekatan saintifik, terutama saat mengeksplorasi buku-buku/ informasi untuk menyelesaikan masalah di lembar latihan/ lembar kerja, akibatnya siswa belum dapat mengerjakan tugas kelompok yang dibagi, dan belum dapat menyimpulkan materi pada akhir pertemuan. Kekurangan-kekurangan yang terjadi pada siklus 1 diperbaiki pada siklus 2

Pembelajaran dengan pendekatan saintifik pada siklus 2 dilaksanakan 4 kali pertemuan. Materi yang dibahas adalah fungsi kuadrat. Total waktu untuk siklus 2 adalah 9x40 menit, dan evaluasi siklus 2 selama $1 \times 40$ menit. Hasil observasi skor rata-rata pada siklus 2 adalah 18,50 dengan kategori sangat aktif.

Evaluasi siklus 2 diikuti oleh 38 siswa. Evaluasi siklus 2 berbentuk uraian yang berjumlah 4 soal. Hasil tes kemampuan komunikasi matematis siswa pada siklus 2 diperoleh 52,63\% yang tuntas, namun nilai rata-rata nilai meningkat menjadi 71,38. Dari hasil ini, indikator kinerja tidak tercapai pada siklus 2. Untuk itu, guru melakukan refleksi terhadap kekurangan-kekurangan yang terjadi sehingga mengakibatkan ketuntasan belajar klasikal belum tercapai.

Tidak tercapainya indikator kinerja dipengaruhi oleh kekurangan-kekurangan yang terjadi diantaranya masih terdapat siswa yang tidak memperhatikan pelajaran dengan sungguhsungguh, siswa belum dapat mengerjakan tugas kelompok yang dibagi sesuai waktu yang telah ditetapkan, dan soal latihan yang kurang bervariasi.

Secara umum, hasil observasi aktivitas siswa dan capaian kemampuan komunikasi matematis siswa siklus 1 dan 2 dapat dilihat pada Gambar 1 dan 2.

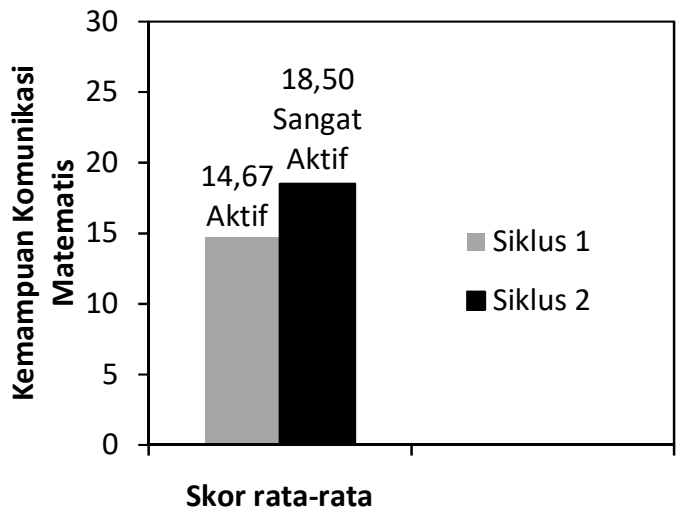

\section{Gambar 1: Skor rata-rata observasi aktivitas} siswa siklus 1 dan 2

Berdasarkan gambar 1, secara keseluruhan skor rata-rata observasi aktivitas siswa mengalami peningkatan dari siklus 1 ke siklus 2 . Pada siklus 1 berkategori aktif dan siklus 2 menjadi sangat aktif. Hasil ini menunjukkan bahwa aktivitas siswa tercapai berdasarkan indikator kinerja yang ditetapkan. Hal ini disebabkan karena siswa semakin terbiasa menerima pembelajaran dengan pendekatan saintifik. Semakin hari semakin banyak siswa yang ikut terlibat dan aktif dalam diskusi menyelesaikan masalah dalam lembar latihan/ lembar kerja. Pembelajaran disetting dalam kelompok-kelompok kecil (berjumlah 3-4 orang). Siswa mendiskusikan masalah dalam lembar kerja dengan kelompok masing-masing. Hasil penelitian Hayati \& Romdhini [20], pembagian siswa dalam kelompok-kelompok kecil membuat aktivitas siswa meningkat. Keaktifan siswa dalam proses pembelajaran menyebabkan interaksi yang tinggi antara siswa dengan guru, atau antar siswa itu sendiri.

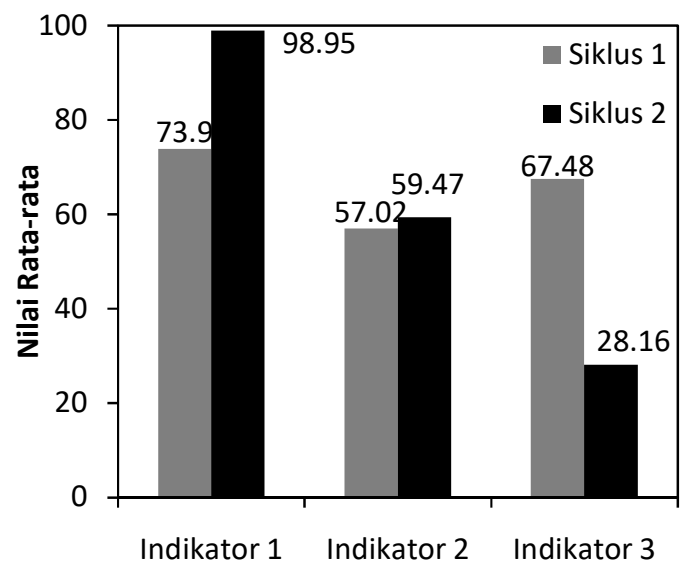

Gambar 2. Nilai Rata-rata Berdasarkan Indikator Kemampuan Komunikasi Matematis Siswa Siklus 1 dan 2 
Secara umum, nilai rata-rata kemampuan komunikasi matematis siswa pada siklus 168,50 meningkat menjadi 71,38 pada siklus 2. Hasil penelitian ini sesuai dengan beberapa penelitian yang diperoleh oleh Deswita, et. al [21], Fadhlilaturrahmi [22], yaitu kemampuan komunikasi matematis siswa meningkat dengan pendekatan saintifik. Namun, ketuntasan klasikal yang dicapai pada PTK ini masih jauh dari $85 \%$ (dengan $\mathrm{KKM} \geq 70$ ). Ketuntasan klasikal pada siklus 1 hanya $26,23 \%$ (hanya 10 orang yang tuntas), dan siklus 2 meningkat menjadi 52,63\% (20 orang yang tuntas). Faktor-faktor yang mempengaruhi tidak tercapainya ketuntasan belajar secara klasikal antara lain dari faktor siswa yaitu kurangnya motivasi dan minat belajar, dan dari faktor guru antara lain kurangnya pengelolaan kelas, kurangnya metode penguasaan, kurangnya hubungan antara guru dan siswa [23]. Hal ini mendukung temuan observasi pada PTK ini, yaitu masih terdapat siswa yang tidak memperhatikan (kaitannya dengan motivasi dan minat siswa), kurangnya waktu diskusi menyelesaikan masalah (kaitannya dengan kurangnya kemampuan guru dalam mengelola kelas), dan kurangnya variasi soal (kaitannya dengan kurangnya penguasaan guru dalam metode dan bahan ajar).

Berdasarkan gambar 2, indikator yang mengalami peningkatan adalah indikator 1 (menggunakan pendekatan bahasa (notasi, istilah, lambang), representasi matematis (rumus, diagram, gambar, tabel, grafik) untuk menyatakan/ menjelaskan informasi matematis) dan indikator 2 (menjelaskan ide, situasi, dengan gambar, ekspresi, atau bahasa sendiri dengan tulisan). Namun indikator 3 (menyusun argumen, dan membuat kesimpulan) mengalami penurunan nilai rata-rata.

Indikator 1 menunjukkan peningkatan nilai rata-rata siklus 1 dan siklus 2 . Nilai rata-rata siklus 1 73,9 meningkat di siklus 2 menjadi 98,95. Evaluasi indikator 1 adalah menggunakan pendekatan bahasa dan representasi matematis untuk menjelaskan informasi statistis, yaitu menentukan akar persamaan kuadrat dengan salah satu metode (pemfaktoran, melengkapkan kuadrat sempurna, dan rumus kuadratik), menggambar grafik fungsi kuadrat, dan menentukan sumbu simetri dan nilai optimumnya. Menurut Guner [5], metode yang paling banyak digunakan adalah pemfaktoran. Jika siswa tidak bisa menyelesaikan persamaan kuadrat dengan pemfaktoran, siswa biasanya tidak mencoba mencari akar dengan metode yang berbeda atau jawabannya tidak lengkap/ kosong. Demikian juga dengan hasil penelitian pada siklus 1, bahwa sebagian besar siswa menjawab benar menentukan akar persamaan kuadrat dengan metode pemfaktoran, namun siswa mengalami kesulitan ketika menentukan akar dengan dua metode yang lain. Hampir semua siswa dapat menggambar grafik fungsi kuadrat dengan benar, dan menentukan sumbu simetri dan nilai optimum grafik fungsi kuadrat. Hasil dari indikator 1 menunjukkan bahwa sebagian besar siswa dapat menyelesaikan soal yang bersifat prosedural/ menggunakan rumus. Hal ini sesuai dengan hasil penelitian [3, 10, 11]. Ini artinya siswa masih berada pada level prosedural/ instrumental dan belum mencapai level relasional.

Indikator 2 menunjukkan peningkatan nilai rata-rata siklus 1 dan siklus 2 . Nilai rata-rata siklus 1 57,02 meningkat di siklus 2 menjadi 59,47. Dibandingkan dengan indikator 1, pada indikator 2 walaupun meningkat namun nilai rata-ratanya tergolong rendah, yaitu kurang dari 70. Siswa mengalami kesulitan menentukan/ menjelaskan fungsi kuadrat yang melalui titik-titik koordinat. Sebagian besar siswa tidak dapat melakukan langkah-langkah penyelesaian dengan tepat, dan cenderung melakukan banyak kesalahan. Hasil serupa diperoleh Tiffany et. al. [12], capaian yang paling rendah ditemukan pada indikator menjelaskan ide matematis secara tertulis. Siswa tidak dapat merubah titik-titik koordinat yang diketahui menjadi persamaan kuadrat matematis dan menganalisisnya.

Indikator 3 menunjukkan penurunan nilai rata-rata siklus 1 dan siklus 2. Nilai rata-rata siklus 167,48 menurun di siklus 2 menjadi 28,16 . Indikator 3 berkiatan dengan pemecahan masalah. Siswa mengalami kesulitan merubah soal cerita menjadi model matematis. Sehingga hal ini berpengaruh pada langkah selanjutnya, siswa tidak dapat menyusun arguemn dan membuat kesimpulan yang sesuai dengan konteks masalah. Sarwadi \& Shahrill [9] mengungkapkan bahwa, siswa sering tidak sadar/ mengetahui kesalahan yang dibuat. Kesalahan itu akibat kurangnya pengetahuan sebelumnya, tidak dapat membuat hubungan antara konsep satu dengan konsep yang lain. Didis \& Erbas [6] menemukan bahwa siswa kesulitan dalam menyelesaikan masalah yang disajikan dengan kata-kata. Untuk itu, Makonye \& Nhlanhla [8] merekomendasikan pembelajaran yang dikoneksikan dengan tugas. Tugas yang diberikan didesain sehingga siswa memiliki pengalaman dengan dirinya sendiri berkaitan proses matematis seperti mengidentifikasi masalah dan mengumpulkan informasi terkait masalah [24]. Proses tersebut didukung oleh diskusi, komunikasi baik secara lisan dan tulisan. Dalam pembelajaran pendekatan saintifik, siswa dibiasakan untuk berpikir menggunakan kaidah dan langkah ilmiah. Proses pembelajaran lebih penting dibandingkan hasil pembelajaran [16]. Dengan demikian, langkah-langkah dalam PTK harus disiapkan dengan baik, sehingga proses pembelajaran berjalan dengan baik. Hasil refleksi pada siklus 2 masih terdapat beberapa kekurangan yang menjadi 
acuan guru untuk memperbaiki kemampuan komunikasi matematis siswa untuk pertemuan selanjutnya.

\section{KESIMPULAN}

Berdasarkan hasil penelitian dan pembahasan di atas, maka dapat disimpulkan:

a. Penerapan pendekatan scientific dapat meningkatkan aktivitas belajar siswa kelas IXH SMP Negeri 5 Mataram pada materi pokok Persamaan dan Fungsi Kuadrat tahun ajaran 2018/2019. Indikator keberhasilan tercapai pada aktivitas belajar siswa.

b. Penerapan pendekatan saintifik dapat meningkatkan kemampuan komunikasi matematis siswa kelas IX-H SMPN 5 Mataram materi pokok persamaan dan fungsi kuadrat berdasarkan nilai rata-rata dari siklus 1 yang meningkat ke siklus 2. Namun belum memenuhi kriteria ketuntasan belajar klasikal.

c. Faktor-faktor penyebab ketuntasan belajar klasikal belum tercapai, yaitu masih terdapat siswa yang tidak memperhatikan (kaitannya dengan motivasi dan minat siswa), kurangnya waktu diskusi menyelesaikan masalah (kaitannya dengan kurangnya kemampuan guru dalam mengelola kelas), dan kurangnya variasi soal (kaitannya dengan kurangnya penguasaan guru dalam metode dan bahan ajar).

\section{UCAPAN TERIMA KASIH}

Tim Peneliti mengucapkan terima kasih kepada Program PDS (Penugasan Dosen di Sekolah) FKIP Universitas Mataram tahun 2018, yang memfasilitasi pembiayaan penelitian tindakan kelas ini.

\section{DAFTAR PUSTAKA}

[1] Larson, R. \& Hodgkins A. 2009. College Algebra with Applications for Business and Life Sciences, Enhanced Edition, USA: Brooks/ Cole Cencage Learning.

[2] Sağlam, R. \& Alacacı, C. 2012. A comparative analysis of quadratics unit in Singaporean, Turkish and IMDP mathematics textbooks. Turkish Journal of Computer and Mathematics Education, 3(3), 131-147.

[3] Didiş, M. G. Baş, S., \& Erbaş, A. K. 2011. Students' reasoning in quadratic equations with one unknown. Proceedings of the 7th Congress of the European Society for Research in Mathematics Education (CERME 7), 479-489.
[4] Kotsopoulos, D. 2007. Unraveling student challenges with quadratics: A cognitive approach. Australian Mathematics Teacher, 63(2), 19-24.

[5] Guner, P. 2017. High School Students' Achievement of Solving Quadratic Equations. Bartin University Journal of Faculty Education, 6 (2): 447-467.

[6] Didiş, M. G. \& Erbaş, A. K. 2015. Performance and Diddiculties of Students in Formulating and Solving Equations with one Unknown. Educational Sciences, Theory and Practice, 15 (4): 1137-1150.

[7] Usman, M. H. 2015. Analysis of Problem Solving Difficulties with Quadratic Equations among Senior Secondary Schools Students in Zaria, Nigeria. Journal of Science, Technology \& Education, 3 (3): 1-9.

[8] Makonye, J. \& Nhlankla, S. (2014). Exploring 'Non-Science' Grade 11 Learners' Errors in Solving Quadratic Equations. Mediterranean Journal of Social Sciences, 5(27), 634-644.

[9] Sarwadi, H. R. H. \& Shahrill, M. (2014). Understanding students' mathematical errors and misconceptions: The case of year 11 repeating students. Mathematics Education Trends and Research: 1-10.

[10] Vaiyavutjamai, P., \& Clements, M. A. (2006). Effects of classroom instruction on students' understanding of quadratic equations. Mathematics Education Research Journal, 18(1), 47-77.

[11] Vaiyavutjamai, P., Ellerton, N. F., \& Clements, M. A. (2005). Students' attempts to solve two elementary quadratic equations: A study in three nations. Proceedings of the $28^{\text {th }}$ Annual Conference of the Mathematics Education Research Group of Australia, 735 742 .

[12] Tiffany, F., et. al. 2017. Analysis Mathematical Communication Skills Student at the Grade IX Junior High School. International Journal of AdvanceResearch and Innovative Ideas in Education. 3(2):2160-2164.

[13] National Council of Teachers of Mathematics (NCTM). 2000. Principle and Standards for School Mathematics. Reston, VA: NCTM. 
[14] Lomibao, L. S., Luna, C. A., \& Namoco, R. A. 2016. The Influence of Mathematical Communication on Students' Mathematics Performance and Anxiety. American Journal of Educational Research. 4 (5): 378-382.

[15] Baroody, A. J 1993. Problem Solving, Reasoning, and Communicating, $K-8$ : Helping Children Think Mathematically. New York: Macmillan Publishing Company.

[16] Bayuaji, P., Hikmawati, H., \& Rahayu, S. (2017). Pengaruh Model Pembelajaran Kooperatif Tipe Student Facilitator And Explaining (Sfae) Dengan Pendekatan Saintifik Terhadap Hasil Belajar Fisika. Jurnal Pijar Mipa, 12(1).

[17] Ishak, M., Jekti, D. S. D., \& Sridana, N. (2017). Pengaruh Penerapan Pendekatan Saintifik Menggunakan Model Pembelajaran Discovery Dan Kooperatif Tipe Stad Terhadap Kemampuan Berpikir Kreatif Peserta Didik SDN 13 Ampenan. Jurnal Pijar Mipa, 12(1).

[18] Anggraeni, D., Sumarmo, U., \& Kusnandi. 2012. Meningkatkan Kemampuan Pemahaman dan Komunikasi Matematik Siswa SMK melalui Pendekatan Kontekstual dan Strategi Formulate-Share-Listen-Create (FSLC). Dalam Kumpulan Makalah Berpikir dan Disposisi Matematik serta Pembelajarannya. 2014. Bandung: UPI.

[19] Mettetal, G. 2012. The What, Why and How of Classroom Action Research. Journal of Scholarship of Teaching and Learning, 2 (1): 6-13.

[20] Hayati, L., \& Romdhini, M. U. 2012. Penerapan Pendekatan Pemecahan Masalah melalui Belajar dalam Kelompok Kecil untuk Meningkatkan Prestasi Belajar pada mata kuliah Teori Peluang. Jurnal Teknologi Pendidikan, 16 (2).

[21] Deswita, R., Kusumah, Y. S., \& Dahlan, J. A. 2018. Peningkatan Kemampuan Komunikasi Matematis Siswa Melalui Model Pembelajaran CORE dengan Pendekatan Saintifik. Edumatika Jurnal Riset Pendidikan Matematika, 1 (1): 35-43.

[22] Fadhilaturrahmi. 2017. Penerapan Pendekatan Saintifik untuk Meningkatkan Kemampuan Komunikasi Matematik Peserta Didik di
Sekolah Dasar. Jurnal Pendidikan Dasar, 9 (2), 109-118.

[23] Saam, Z. S. Z., \& Yakub, E. Y. E. (2015). Faktor-faktor Penyebab Siswa Memperoleh Nilai Dibawah $\mathrm{Kkm}$ pada Mata Pelajaran Matematika, Sains, dan IPS Sdn 010 Bangko Sempurna. Jurnal Online Mahasiswa Fakultas Keguruan dan Ilmu Pendidikan Universitas Riau, 2(1), 1-17.

[24] Rahman, R. A., Yusof, Y. M., Kashefi, H., \& Baharun, S. (2012). Developing Mathematical Communication Skills of Engineering Students. Procedia - Social and Behavioral Sciences, 46, 5541-5547. 